\title{
Suvaitsevaisuuskasvatuksen haasteita
}

\section{Wahlström, Riitta 1996. Suvaitsevuuteen kasvattaminen. Opetus 2000, WSOY.}

1970- ja 1980 -luvuilla puhuttiin rauhankasvatuksesta ja kansainvälisyyskasvatuksesta. Niistä rauhankasvatuksella oli enemmän poliittista väriä. Unescon suositus vuodelta 1974 ("Kasvatus kansainväliseen ymmärtämykseen, yhteistyöhön ja rauhaan sekä ihmisoikeuksien ja perusvapauksien opetus") pitää tärkeänä, että kaikkiin koulutuksen tasoihin ja sen muotoihin sisältyy kansainvälinen ja maailmanlaajuinen tarkastelutapa. Koulutuksessa tulee näkyä kunnioitus kaikkia kansoja ja niiden kulttuuria sekä arvoja ja elämäntapaa kohtaan. Koulutuksessa korostetaan mm. maailmanlaajuisen riippuvuuden ja yhteistyön tarpeen ymmärtämistä.

Unescon (1974) suosituksen mukaan opetuksen "olisi osaltaan edistettävä maailmanrauhan vahvistamista sekä taistelua kolonialismin ja 'uuskolonialismin sekä rasismin, fasismin ja apartheidin kaikkia ilmenemismuotoja vastaan, samoin kuin kaikkia sellaisia ideologioita vastaan, jotka kylvävät kansallisuus- ja rotuvihaa ja ovat tämän suosituksen vastaisia. "

Suomessa etenkin Helena Kekkonen ja Helena Allahwerdi ovat olleet pitkään edistämässä rauhan - ja kansainvälisyyskasvatuksen tavoitteita. Heidän ja monen muun aktiivisuuden ansiosta Suomessa on kautta vuosien puhuttu kansainvälisyyskasvatuksesta ja sen taustalla olevasta ihmiskuvasta. Vaikka varmasti paljon hyvää ja merkittävää on saatu aikaan, kansojen välistä yhteisymmärrystä on varsin vaikea edistää umpisuomalaisessa maisemassa. Kansainvälisyyskasvatus onkin kärsinyt konkretian puutteesta. Toisaalta sen heikkous on ollut katseen kohdistaminen liian etäälle, meidän näkökulmastamme eksoottisiin maihin ja kansoihin. Pahimmassa tapauksessa kansainvälisyyskasvatus on lisännyt ennakkoluuloja kertomalla eksoottisia yksityiskohtia, lue: kummallisuuksia, muista kansallisuuksista. Suomessa on siis aivan käytännön syistä ollut vaikea kansainvälistyä kotinurkilla. Vasta kun tänne on tullut pakolaisia ja muita maahanmuuttajia, kansainvälisyys ja kohtaaminen ovat alkaneet koskettaa tavallisia kansalaisia arkipäivän elämässä. Samoin vasta nyt on löydetty vanhat vähemmistöt, joiden kanssa olisi jo vuosikymmenet voinut harjoitella erilaisuuden kohtaamista ja hyväksymistä. Parempi myöhään kuin ei milloinkaan ...

Mutta niitä termiä käytettäisiin? Rauhankasvatus kuulostaa vanhanaikaiselta. Kansainvälisyyskasvatuskaan ei ole oikein muodissa. Riitta Wahlström on valinnut suvaitsevuuskasvatuksen. Se ei olekaan hullumpi valinta: suvaitsevaisuus ei välttämättä erottele sen tarkemmin sitä, mikä tai kuka on suvaitsemisemme kohteena, kyseessä on kyky suhtautua suvaitsevasti yleensä ottaen erilaisuuteen ja erilaisiin ihmisiin.

Wahlström kuvaa kirjansa alkupuolella Suomen vähemmistöistä romaaneja, saamelaisia sekä pakolaisia. Ennakkoluulojen syntyä ja niiden yhteyttä itsetuntoon, nationalismiin ja rasismiin käsitellään kirjan toisessa jaksossa, ja kolmannessa pohditaan suvaitsevaisuuskasvatuksen ideologiaa ja periaatteita. Kirjassa on lukuisia hyviksi havaittuja, monentasoisia toimintaehdotuksia ja -ideoita kuhunkin aihepiiriin liitettyinä.

Suvaitsevuuteen kasvattaminen on hyvä, ajan tasalla oleva peruskirja etenkin niille, jotka eivät ole vielä liiemmin perehtyneet kirjan aihepiiriin. Teoksessa on selkeä jäsentely ja ulkonäkö. Se on helppolukuinen ja siinä esitetyt toimintaideat ovat vaivattomasti toteutettavissa. Toimintaideat on koottu Wahlströmin omista kokeiluista sekä eri järjestöjen nykyisin jo lukuisista suvaitsevuusaineistoista (mm. SPR, UNICEF, seurakunnat). 
Wahlströmin mukaan suvaitsevuuskasvatuksen lähtökohtana on ekohumanistinen ihmiskuva ja uudistavan oppimisen oppimiskäsitys. Uudistavaan oppimiseen nivoutuu kokemuksellinen oppiminen. Opetusmenetelmät ovat usein ongelmakeskeisiä. Kasvatusperiaatteisiin kuuluvat $\mathrm{mm}$. yhteistoiminnallisuus, tasavertaisuus opettajan ja oppijan välillä, refleksiomahdollisuus ja oppijan omien vaikutusmahdollisuuksien arvostaminen. Suvaitsevuuteen kasvattavat opetusohjelmat voidaan jakaa kolmeen osaan. Ensiksi opetetaan ymmärtämään omaa itseä ja omaa kulttuuria, toiseksi opetetaan tunnistamaan erilaisuutta omassa ryhmässä ja kolmanneksi tutustutaan yhteen tai useampaan vieraaseen kulttuuriin.

\section{Yhteiskunnan realiteetteihin kuuluvat myös ristiriidat}

Wahlströmin suvaitsevuuteen kasvattaminen lankeaa samaan kuoppaan entisen kansainvälisyyskasvatuksen kanssa: yhteiskunnallisia realiteetteja ja rakenteita ei ole otettu huomioon, vaikka ne luovat ne puitteet, jossa niin suvaitsevat kuin suvaitsemattomat elelevät. Ilman yhteiskunnallista kosketuspintaa suvaitsevuus- ja kansainvälisyyskasvatus jäävät hyvää tarkoittaviksi muotopuoliksi. Tai - mikä minua on aina hämmästyttänyt - maailmanlaajuinen rakenteellinen epätasa-arvo ja epäoikeudenmukaisuus nähdään ja kuvataan selkeästi, mutta se mitä tapahtuu lähellä, jää usein huomiotta. Tästä on konkreettisena esimerkkinä se, millä tavoin suomalaiset ovat kohdelleet omia vähemmistöjään ja kuinka vähän siihen on kukaan meistä puuttunut. Eikä tässä ole edes mitään opittu - ajatellaanpa vain hiljattain käytyä keskustelua homoseksuaalien oikeudesta rekisteröityä, tai pakolaisten asemaa Suomessa: meidän enemmistöön kuuluvien hiljaisuus oli paljon puhuva. Suomalainen yhteiskunta on kova ja erilaisuutta torjuva, siihen pitäisi myös suvaitsevaisuuskasvatuksella puuttua.

Monikulttuuriseen yhteiskuntaan kuuluu jo ajatuksenakin väistämättä ristiriitoja. Se ettei niistä puhuta, ei saa niitä häviämään. Monikulttuurisessa yhteiskunnassa eri ryhmän kuuluvat ihmiset joutuvat määrittelemään rooliaan suhteessa muihin sekä neuvottelemaan keskenään ja tekemään päätöksiä siitä, miten yhteiskunta järjestetään. Esimerkiksi päätökset resurssien jaosta eri ryhmien kesken ovat vaikeita.

Suomessa (joka ei todellakaan toistaiseksi ole monikulttuurinen yhteiskunta) ei ole vielä kokemusta siitä, minkä tyyppisiä ristiriitoja monikulttuurisuus tuo mukanaan. On hyvä seurata tässä asiassa edistyneempien maiden kuten Kanadan ja Ruotsin kokemuksia; esiin nousseita ongelmia ja niiden ratkaisuyrityksiä. Ainakin on syytä myöntää, että monikulttuurinen yhteiskunta ei ole ristiriidaton onnela, jossa toisiaan suvaitsevat ihmiset tekevät hedelmällistä yhteistyötä. Jos ajattelen suvaitsevuuskasvatuksen mahdollisuuksia aikuiskasvatuksen kentässä, pidän ensiarvoisen tärkeänä, että suvaitsevuuskasvatus ei väistä näitä mahdollisia ristiriitoja ja konflikteja vaan nostaa ne esiin analyysia ja käsittelyä varten, jotta niihin voidaan muokata ja luoda ratkaisumahdollisuuksia.

Kielen valinta on vaikea asia. Suvaitsevuuteen kasvattaminen - kirjan aiheeseen sopii muu kuin pelkistetty asiatyyli. Wahlström ei käytä tieteellistä tai vaikeaselkoista kieltä vaan pikemminkin jutustelevaa, me-muotoista. Se sopiikin hyvin esimerkiksi opintokerhojen vetäjille ja ryhmien vapaaehtoisohjaajille, mutta kun kirjan kohderyhmänä ovat muun muassa opettajat, tuntuu valittu tyyli liian yksinkertaiselta.

Kirjan loppuosan vinkit suomalaiselle satunnaiselle matkaajalle tai liikemiehelle eivät ole mielestäni omiaan kasvattamaan suvaitsevuutta vaan pikemminkin luovat esteitä järkevien, kunnioitukseen perustuvien, tasa-arvoisten kontaktien solmimiselle. On vaikea suhtautua luontevasti muunmaalaiseen puhekumppaniin, jos mielessään joutuu koko ajan muistelemaan esimerkiksi: Kiinassako kello on kuoleman symboli? mitä krysanteemit viestittävät ranskankielisille? saako istua jalat ristissä vai ei ja jos niin mitä se tarkoittaa? saako sanoa ei vai ei?

\section{Johanna Matikainen}

Kirjoittaja on työskennellyt mm. Hämeen lääninhallituksen maahanmuuttajaprojektissa, SPR:n Hämeen piirin pakolaissihteerinä sekä monien suvaitsevuus-, pakolais- ja kansainvälisyyskou- 
lutustilaisuuksien suunnittelijana ja järjestäjänä. Johanna Matikainen on julkaissut aineistot Maahanmuuttajien osallistuminen. Viiden paikkakunnan kokemuksia monikulttuurityöstä Hämeen läänissa. (Sosiaali- ja terveysministeriön monisteita 1996:-2), Kirjava Punainen Risti. Työkaluja osastojen monikulttuurisuustyöhön. (SPR:n keskustoimisto, painossa, 1996) sekä Autetaan maailmaa - opettaja-aineistoa. Kansainvälisyys- ja kehityskysymykset. (SPR:n keskustoimisto, 1993). 